\title{
ISOLASI DAN IDENTIFIKASI JAMUR PATOGEN PADA AIR SUMUR DAN AIR SUNGAI DI PEMUKIMAN WARGA DESA KARANGWANGI, CIANJUR, JAWA BARAT
}

\author{
Ida Indrawati ${ }^{1}$, Sarah Dewi Fakhrudin ${ }^{2}$ \\ ${ }^{1,2}$ Department of Biology, Faculty of Mathematics and Natural Sciences, Padjadjaran University. \\ Jl. Raya Bandung-Sumedang Km 21 Jatinangor West Java, Indonesia. Tel./Fax08122170547/7796412 \\ email: ${ }^{1}$ ida.indrawati81@gmail.com
}

Diterima:02 Juni 2016 Ditinjau : 14 Oktober 2016 Disetujui :01 November 2016

\begin{abstract}
Abstrak. Penelitian Isolasi dan Identifikasi Jamur Patogen pada Air Sumur di Wilayah Pemukiman Warga RW 05-08 dan Air Sungai Cilaki, Desa Karangwangi, Cianjur, Jawa Barat, bertujuan untuk melihat keanekaragaman jamur patogen yang terdapat pada air sumur RW 05-08 dan air sungai Cilaki. Metode yang digunakan dalam penelitian ini adalah metode deskriptif eksploratif untuk menentukan lokasi pengambilan sampel. Dilakukan pengenceran dari sampel air kemudian dilakukan metode pour plate dengan medium Agar Sabouraud lalu diinkubasi selama 72-96 jam. Koloni jamur dihitung dengan metode Total Plate Count (TPC). Identifikasi dilakukan secara makroskopis dengan melihat bentuk dan warna koloni jamur, serta secara mikroskopis dengan cara moist chamber. Hasil jumlah koloni jamur patogen terbanyak ditemukan pada sumur RW 06. Hasil penanaman seluruh sampel air sumur dan sungai, ditemukan 9 spesies jamur patogen, genus Penicillium sebanyak 2 spesies, Trichophyton sebanyak 3 spesies, Geotrichum sebanyak 2 spesies, Microsporum dan Lichtheimia masing-masing sebanyak 1 spesies. Dari hasil yang didapat, disimpulkan bahwa air sumur di wilayah RW 05-08 dan air sungai Cilaki di Desa Karangwangi kurang baik jika digunakan secara langsung karena banyaknya jamur patogen yang terkandung di dalamnya.
\end{abstract}

Kata Kunci: Jamur, Sumur, Sungai, Total Plate Count.

\begin{abstract}
Isolation and Identification of Pathogenic Fungi on Well Water Territory Residential Residents RW 05-08 and Cilaki River Water, Karangwangi village, Cianjur, West Java research, aiming to see the diversity of fungal pathogens found in well water RW 05-08 and Cilaki river water. The method used in this study is descriptive exploratory method for determining the location of sampling of water in wells in $R W 05$ to $R W 08$ and Cilaki river. Do dilution of water samples and then performed pour plate method with Sabouraud agar medium and incubated for 72-96 hours. Fungal colonies which have grown calculated by the method Total Plate Count (TPC). Identification is done macroscopically by looking at the shape and color of fungal colonies and microscopically by creating a wet media room (moist chamber). The result is the highest number of colonies of pathogenic fungi found in well water samples RW 06. From the planting around the wells and river water samples, found as many as nine species of fungal pathogens, with as many as two species of the genus Penicillium, Trichophyton many as three species, Geotrichum much as 2 species, Microsporum and Lichtheimia each as much as one species. From the results obtained, it can be concluded that water wells in the area RW 05-08 and Cilaki river water in Karangwangi village less well if used directly because of the large number of pathogenic fungi colonies contained there in.
\end{abstract}

Keywords : Pathogenic Fungi, Water, Well, River, Pour Plate, Total Plate Count, Moist Chamber

\section{PENDAHULUAN}

Air yang digunakan untuk keperluan sehari-hari harus air bersih yang kualitasnya memenuhi syarat kesehatan dan dapat diminum (Peraturan Menteri Kesehatan RI No.416/Menkes/Per/IX/1990). Kualitas air harus memenuhi beberapa syarat kesehatan baik mikrobiologis, kimiawi, fisik maupun radioaktif (Keputusan Menteri Kesehatan RI No. 907/Menkes/SK/VII/2002). Air minum merupakan kebutuhan utama dalam kehidupan, harus tidak terkontaminasi mikroorganisme patogen, seperti jamur, 
bakteri, virus, dan parasit (Hageskal et al., 2009).

Jamur bisa menjadi kontaminan dalam air minum, merupakan organisme eukariotik dan heterotrofik, terbagi ke dalam kelompok bersel tunggal (uni-selular) dan berfilamen (multi-selular). Penyebarannya dapat dilakukan melalui spora. Jamur juga memproduksi metabolit sekunder, beberapa di antaranya adalah racun. Beberapa spesies dan metabolit yang mereka hasilkan dapat berupa patogen pada manusia atau alergen (Defra, 2011).

Beberapa jamur di lingkungan perairan biasanya zoosporic, dan banyak termasuk dalam filum Chytridiomycota. jamur yang ditemukan di dalam air mencakup jamur uniselular (ragi), tapi kebanyakan jamur yang ditemukan berupa jamur berfilamen (kapang). Jamur ini dapat berpotensi sebagai patogen, alergen, dan mengandung toksin (Hageskal et al., 2009). Sebagai makhluk heterotrof, jamur dapat bersifat parasit obligat, fakultatif, atau saprofit (Cooke, 2009).

Jamur yang hidup di air biasanya bersifat parasit atau saprofit, dan kebanyakan dari kelas Oomycetes. Indonesia yang beriklim tropis menyebabkan air di alam terbuka selalu mengandung mikroorganisme. Kandungan mikroorganisme dalam air alami sangat berbeda tergantung pada lokasi dan waktu. Apabila air merembes dan meresap melalui tanah, maka air akan membawa sebagian mikroorganisme ke bagian tanah yang lebih dalam. Air tanah pada umumnya paling sedikit mengandung mikroorganisme, dan air tanah yang terdapat pada bagian yang dalam sekali hampir tidak mengandung mikroorganisme. Sebaliknya air permukaan mengandung banyak mikroorganisme yang berasal dari tanah dan dari organisme yang terdapat di danau-danau dan sungai-sungai. Kehadiran mikroorganisme di dalam air akan mendatangkan keuntungan dan kerugian (Waluyo, 2004).

Terdapat 580 spesies jamur air yang diketahui merupakan pengurai pada habitat perairan. Kebanyakan spesies jamur air hidup bebas dan mendapat nutrisi dari sisa-sisa tumbuhan di kolam, danau, dan aliran air. Beberapa jamur air hidup di dalam jaringan yang mati pada tumbuhan. Beberapa jenis jamur air juga parasit pada organisme akuatik, misalnya Saprolegnia, yang hidup menempel pada tubuh ikan atau hewan air lainnya. Saprolegnia berbentuk seperti lapisan selaput (Fardiaz, 1992).

Menurut Reseck (1988), air tanah mengandung zat-zat anorganik maupun zat-zat organik yang merupakan tempat yang baik bagi pertumbuhan dan perkembangan mikroorganisme (kehidupan mikroorganisme). Mikroorganisme yang autotrof merupakan penghuni pertama dalam air yang mangandung zat-zat anorganik. Sel-sel yang mati merupakan bahan organik yang memungkinkan kehidupan mikroorganisme heterotrof. Temperatur juga ikut menentukan populasi mikroorganisme di dalam air.

Air sumur merupakan salah satu sumber utama air minum bagi masyarakat, untuk mendapatkan sumber air tersebut umumnya manusia membuat sumur gali atau sumur pantek. Air tanah sering mengandung zat besi (Fe) dan Mangan (Mn) yang jumlahnya cukup besar. Adanya kandungan $\mathrm{Fe}$ dan Mn dalam air menyebabkan warna air tersebut berubah menjadi kuning-coklat setelah beberapa saat kontak dengan udara.bDisamping dapat mengganggu kesehatan, juga dapat menimbulkan bau yang kurang sedap serta menyebabkan warna kuning pada dinding bak serta bercak-bercak kuning pada pakaian. Oleh karena itu, menurut PP No.20 Tahun 1990, kadar $(\mathrm{Fe})$ dalam air minum maksimum yang dibolehkan adalah 0,3 mg/l, dan kadar Mangan $(\mathrm{Mn})$ dalam air minum yang dibolehkan adalah 0,1 mg/l (Yusuf, 2011). Air sumur pada umumnya lebih bersih daripada air permukaan, karena air yang merembes ke dalam tanah itu telah difiltrasi (disaring) oleh lapisan tanah yang dilewatinya, namun kebersihan air secara kasat mata belum tentu mengindikasikan terbebasnya air tersebut dari kontaminasi jamur, kebersihan pada air sumur sangat berkaitan erat dengan lingkungan sekitar sumur (Yusuf, 2011).

Sungai adalah air tawar dari sumber alami yang mengalir dari tempat yang lebih tinggi ke tempat yang lebih rendah dan menuju atau bermuara ke laut, danau atau sungai yang lebih besar. Arus air di bagian hulu sungai (umumnya terletak di daerah pegunungan) biasanya lebih deras dibandingkan dengan arus 
sungai di bagian hilir. Aliran sungai seringkali berliku-liku karena terjadinya proses pengikisan dan pengendapan di sepanjang sungai. Sungai merupakan jalan air alami.mengalir menuju samudera, danau atau laut, atau ke sungai yang lain, sungai juga salah satu bagian dari siklus hidrologi (Sukadi, 1999). Air dalam sungai umumnya terkumpul dari presipitasi, seperti hujan,embun, mata air, limpasan bawah tanah, dan di beberapa negara tertentu air sungai juga berasal dari lelehan es/ salju.Sungai terdiri dari beberapa bagian, bermula dari mata air yang mengalir ke anak sungai. Beberapa anak sungai akan bergabung untuk membentuk sungai utama. Aliran air biasanya berbatasan dengan saluran dengan dasar dan tebing di sebelah kiri dan kanan.Penghujung sungai di mana sungai bertemu laut dikenali sebagai muara sungai (Sukadi, 1999).

Berdasarkan Peraturan Menteri Kesehatan Republik Indonesia Nomor 416/MENKES/PER/IX/1990 dijelaskan bahwa air adalah air minum, air bersih, air kolam renang dan air pemandian umum. Selanjutnya air minum adalah air yang kualitasnya memenuhi syarat kesehatan dan dapat langsung diminum. Sedangkan air bersih adalah air yang digunakan untuk keperluan sehari-hari yang kualitasnya memenuhi syarat kesehatan dan dapat diminum apabila telah dimasak (Slamet,1996).

\section{BAHAN DAN METODE}

\section{Alat}

Autoklaf, $\mathrm{pH}$ meter, luminar flow, timbangan, bunsen, cawan petri, gelas ukur, heater, Inkubator, kaca obyek, kaca penutup, erlenmeyer, mikro pipet, mikroskop, tabung reaksi, rak tabung, ose, termometer.

\section{Bahan}

Sampel air sumur, air sungai, alkohol $70 \%$, akuades, kertas saring, kloramfenikol, medium Agar Saburoud OXOID, $\mathrm{NaCl}$ Fisiologis, Vaseline.

\section{Metode Penelitian}

Metode yang digunakan dalam penelitian ini adalah metode eksploratif untuk menentukan lokasi pengambilan sampel air di sumur di wilayah RW 05 sampai RW 08, dari masing-masing RW diambil 1 sampel sumur, dan di sungai Cilaki. Isolasi dan identifikasi jenis jamur patogen yang terdapat pada air sumur RW 05 sampai 08 menggunakan metode deskriptif sedangkan sungai Cilaki menggunakan moist chamber.

\section{Metode Pengumpulan Data}

Dalam melakukan pengamatan jamur patogen yang terdapat pada air sumur dan sungai, dilakukan pengambilan sampel air sumur di RW 05 sampai 08 yang hanya diambil 1 sampel sumur dari tiap RW dan pengambilan sampel air sungai Cilaki, Desa Karangwangi.

\section{Cara Kerja \\ Sterilisasi alat dan bahan}

Alat dan bahan disteril menggunakan autoklaf, untuk alat dengan suhu $121^{\circ} \mathrm{C}$ dan tekanan 1 atm selama \pm 20 menit, untuk bahan medium dengan suhu $110^{\circ} \mathrm{C}$ dan tekanan 1 atm selama 10-15 menit.

\section{Prosedur kerja}

Metode yang dipakai adalah metode plate count yang meliputi pengenceran, penanaman ke dalam medium saburaud, dan penghitungan koloni.

\section{Pengambilan Sampel}

Sampel air diambil dengan cara mengaduk air terlebih dahulu hingga tercampur rata dengan menggunakan gayung. Air kemudian diambil dan dimasukkan ke dalam botol sampel steril.

\section{Pengenceran Sampel}

Pengenceran dilakukan dengan seri pengenceran dari $10^{-1}$ sampai $10^{-4}$ Pengenceran ini dilakukan untuk setiap sampel air yang didapat.

\section{Penanaman ke dalam medium}

Medium Agar Saburoud yang telah steril dituangkan secukupnya ke dalam cawan petri. Setelah itu, sebanyak $1 \mathrm{ml}$ dari 2 pengenceran terakhir (pengenceran $10^{-3}$ dan $10^{-4}$ ) dari setiap sampel air dimasukkan ke dalam cawan petri berisi medium, kemudian 
dihomogenisasikan Cawan petri dibungkus dengan kertas dan diinkubasi pada suhu ruang selama 72-96 jam. Penanaman sampel pada medium harus dikerjakan secara aseptis agar tidak terjadi kontaminasi. Setelah jamur tumbuh pada cawan petri, kemudian jamur dibuat kultur murni.

\section{Penghitungan Koloni Jamur}

Koloni jamur yang telah tumbuh kemudian dihitung pada setiap pengenceran dengan rumus perhitungan sebagai berikut:

\section{Identifikasi Jamur}

Identifikasi dilakukan dengan dua cara, yaitu secara makroskopis dan mikroskopis. Pemeriksaan dengan cara makroskopis yaitu dengan melihat bentuk dan warna koloni jamur, sedangkan mikroskopisnya dengan melihat struktur atau susunan dari hifa dan spora jamur. Pemeriksaan dengan mikroskopis dilakukan dengan cara membuat media kamar basah (moist chamber).

Prosedur pembuatan moist chamber:

1. Cawan petri dialasi kertas saring, kemudian letakkan kaca objek dan kaca penutup, lalu sterilkan.

2. Agar Saburoud diteteskan secukupnya pada kaca objek dan dibiarkan membeku.

3. Setelah agar membeku, satu sisi dari tetesan agar ini dipotong.

4. Jamur ditanam pada bagian sisi agar yang dipotong tadi.

5. Oleskan Vaseline pada tiga sisi kaca penutup, kemudian tutup agar yang telah ditanam tadi dengan kaca penutup, dengan bagian yang diberi Vaseline tadi tepat di atas irisan agar yang telah ditanam (dengan maksud untuk memberikan suasana aerob).

6. Untuk memberikan suasana lembab, akuades steril diteteskan pada kertas saring yang ada di dalam cawan petri.

7. Mikrokultur dieramkan selama 24-48 jam pada suhu kamar.

8. Setelah dieramkan, mikrokultur siap diamati langsung di bawah mikroskop.

9. Seluruh langkah yang dilakukan di atas harus dilakukan secara steril

\section{Analisis Data}

Analisis data dilakukan dengan cara mengamati data hasil pengamatan secara deskriptif. Setelah dilakukan identifikasi dengan metode moist chamber, dilanjutkan dengan melakukan perbandingan antara hasil yang terlihat di bawah mikroskop dengan buku literatur "Pictorial Atlas of Soil and Seed Fungi, Morphologies of Cultured Fungi and Key to Species".

\section{HASIL}

\section{Jumlah Koloni Jamur}

Berikut hasil perhitungan jumlah koloni jamur patogen dari setiap sampel air yang diambil.

Tabel 1. Jumlah koloni jamur hasil isolasi dari setiap sampel.

\begin{tabular}{|c|c|c|c|c|}
\hline \multirow{3}{*}{ No. } & \multirow{3}{*}{ Sampel } & \multirow{2}{*}{\multicolumn{2}{|c|}{$\begin{array}{c}\text { Jumlah } \\
\text { Koloni Jamur }\end{array}$}} & \multirow{3}{*}{$\begin{array}{c}\text { Jumlah Sel } \\
\text { Jamur/ml }\end{array}$} \\
\hline & & & & \\
\hline & & $\begin{array}{c}\text { Sampel } \\
1\end{array}$ & $\begin{array}{c}\text { Sampel } \\
2\end{array}$ & \\
\hline \multirow[b]{2}{*}{1.} & Air & & & \\
\hline & $\begin{array}{l}\text { Sumur } \\
\text { RW 05 }\end{array}$ & 2 & 2 & $1,1 \times 10^{4} \mathrm{sel} / \mathrm{ml}$ \\
\hline \multirow{3}{*}{2.} & Air & & & \\
\hline & Sumur & 5 & 5 & $2,75 \times 10^{4} \mathrm{sel} / \mathrm{ml}$ \\
\hline & RW 06 & & & \\
\hline \multirow{3}{*}{3.} & Air & & & \\
\hline & Sumur & 0 & 2 & $10^{4} \mathrm{sel} / \mathrm{ml}$ \\
\hline & RW 07 & & & \\
\hline \multirow{3}{*}{4.} & Air & & & \\
\hline & Sumur & 0 & 2 & $10^{4} \mathrm{sel} / \mathrm{ml}$ \\
\hline & RW 08 & & & \\
\hline \multirow{3}{*}{5.} & Air & & & \\
\hline & Sungai & 2 & 0 & $0,1 \times 10^{4} \mathrm{sel} / \mathrm{ml}$ \\
\hline & Cilaki & & & \\
\hline
\end{tabular}

Dari tabel 1 di atas, dapat diketahui bahwa jumlah sel jamur yang paling banyak terkandung dalam sampel air sumur RW 06. Sumur pada RW 06 ini merupakan sumur yang sangat sederhana, dinding sumurnya masih berupa pahatan tanah, belum dibuat dinding. Lokasi dari sumur di RW 06 ini sangat dekat dengan lokasi kegiatan MCK warga RW 06 dan juga sangat dekat dengan kandang kambing, sehingga tidak mengherankan bahwa air sumur mengandung banyak sel jamur patogen karena pencemaran dari lokasi MCK dan kandang kambing tersebut. 


\section{Identifikasi Jamur}

Berikut merupakan hasil dari spesies jamur patogen dari setiap sampel yang telah teridentifikasi.

Tabel 2. Daftar spesies jamur patogen yang telah teridentifikasi

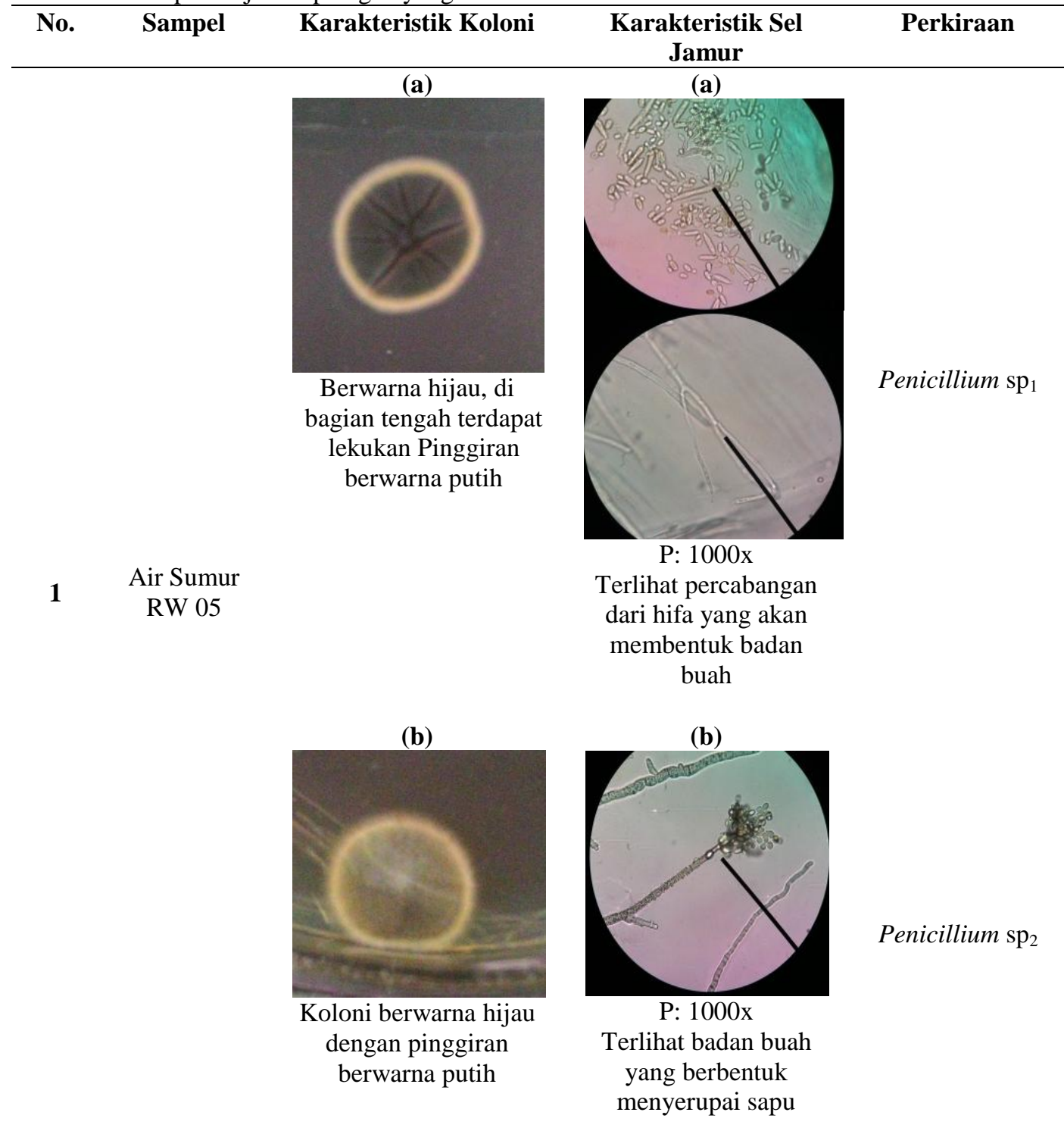

(a)

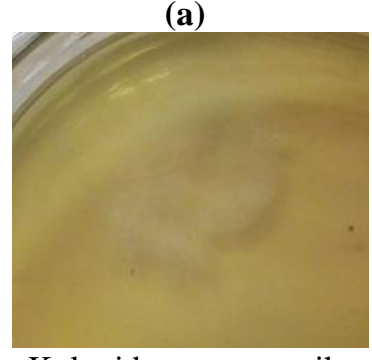

Koloni berwarna putih

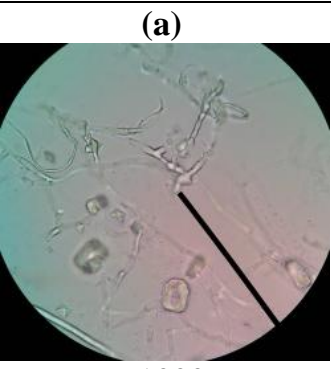

P: $1000 \mathrm{x}$

Terlihat adanya makrokonidia dan mikrokonidia
Trichophyton interdigitale

(b)

Geotrichum sp. 


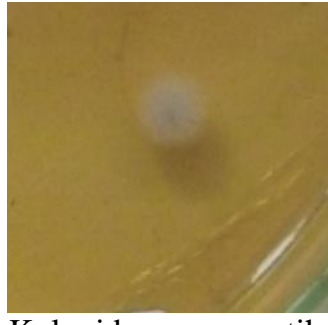

Koloni berwarna putih

(c)

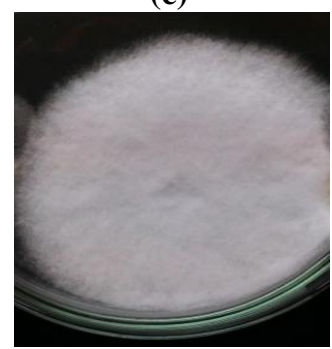

Hifa koloni berwarna putih

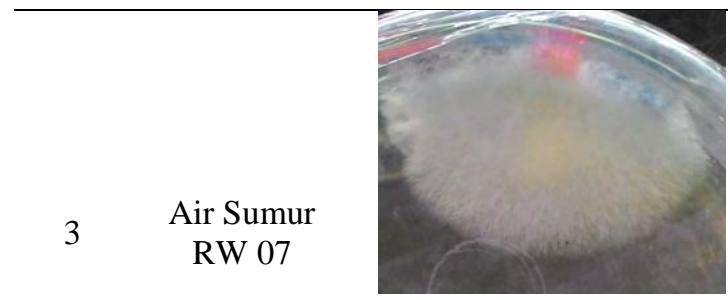

Serabut hifa dari koloni berwarna putih dan hifa agak tipis

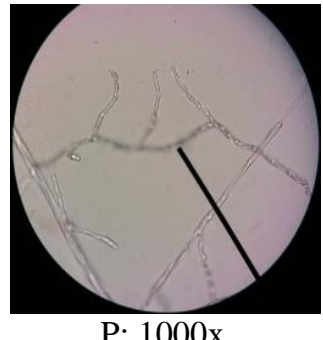

P: $1000 x$

Terlihat arthrokonidia sebagai ciri khas

Geotrichum

(c)

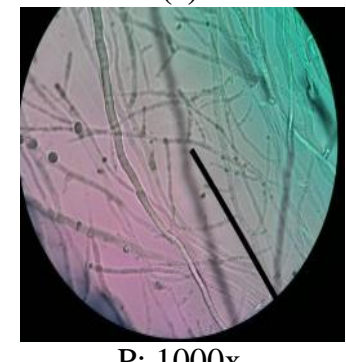

Terdapat makrokonidia dan mikrokonidia

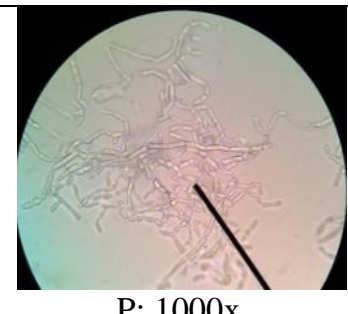

P: $1000 x$

Terlihat arthrokonidia dan hifa berhialin

Trichophyton $\mathrm{sp}_{1}$

Geotrichum candidum (a)

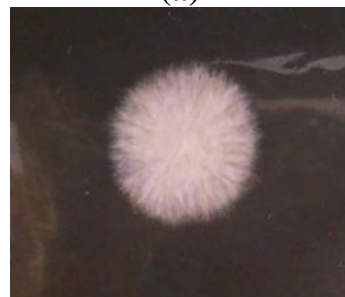

Hifa koloni berwarna putih, berbentuk radial dan seperti kapas

Air Sumur RW 08

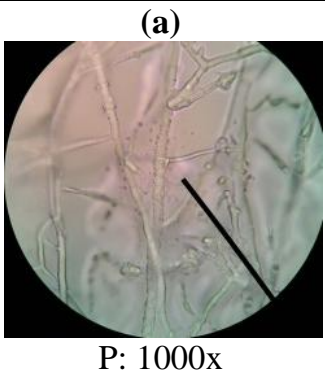

Terlihat makrokonidia yang berbentuk gelendong
Microsporum

canis
Hifa koloni berwarna putih, tekstur seperti kapas

\section{(b)}

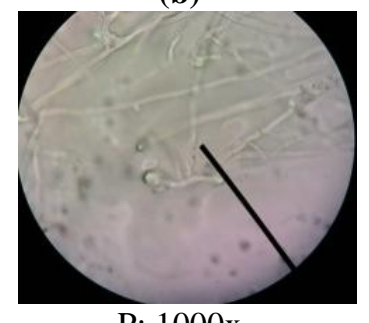

P: 1000x

Terlihat hanya mikrokonidia 


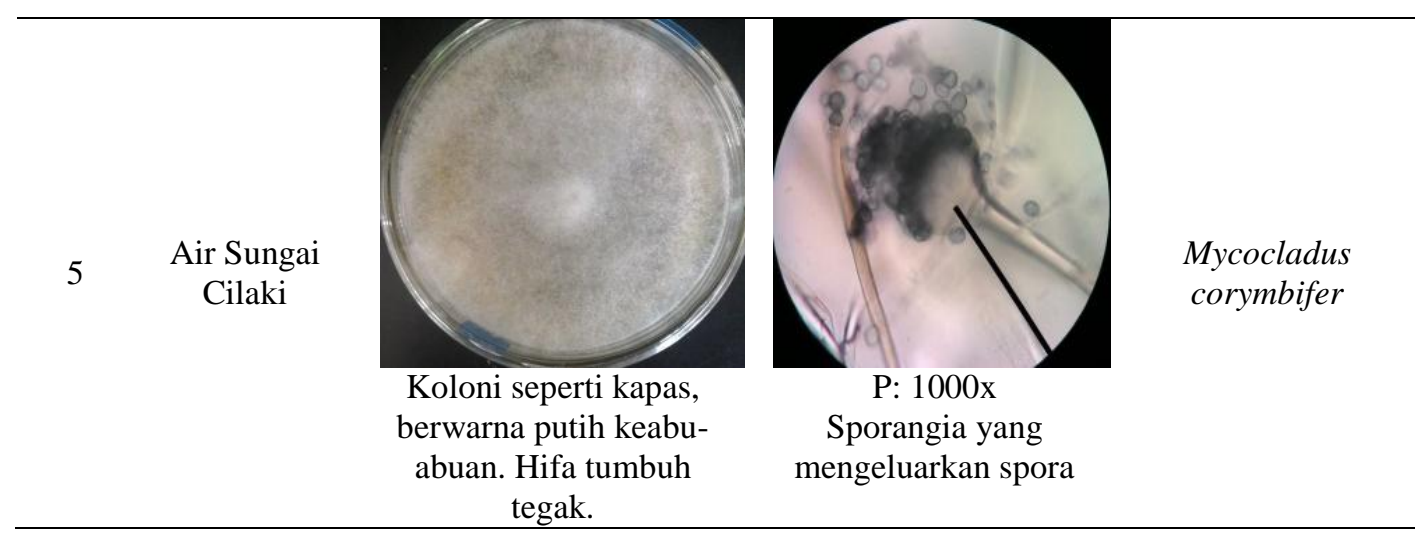

\section{PEMBAHASAN}

\section{Penicillium sp.}

Penicillium termasuk ke dalam kelas Deuteromycetes yang tidak memiliki spora seksual, termasuk juga ke dalam ordo Monilliales dengan konidiofor keluar bebas dari miselia, dan termasuk famili Monililliaceae dengan miselia tidak berwarna atau berwarna cerah. Penicillium sp. biasanya bersepta, badan buah berbentuk seperti sapu yang diikuti sterigma dan konidia yang tersusun seperti rantai. Konidia pada hampir semua species saat masih muda berwarna hijau kemudian berubah menjadi kecoklatan (Purwantisari dan Rini, 2009).

Koloni Penicillium sp. biasanya memiliki pertumbuhan yang sangat cepat, berwarna hijau, terkadang putih dan sebagian besar memiliki konidiofor. Konidiofor tunggal (mononematus) atau majemuk (synematous), terdiri dari batang tunggal membagi beberapa phialid (sederhana/monoverticillata). Semua sel diantara metula dan batang berpotensi menjadi cabang. Percabangan satu tingkat (biverticillata-simetris), percabangan dua tingkat (biverticillata asimetris/terverticillata), serta tiga macam atau lebih tingkatan cabang (quaterverticillata). Phialid merupakan struktur yang menopang konidia, berbentuk silindris di bagian basal yang menyempit di bagian leher, atau lancoelate (kurang lebih sebagian basal tertanam pada bagian ujung pucuk). Konidia berbentuk rantai panjang, divergent atau kolom, globular, elips atau fusiform, transparan atau kehijauan, dengan dinding mulus atau bergelombang (Gandjar, $d k k, 1984$ dalam Purwantisari dan Rini, 2009).

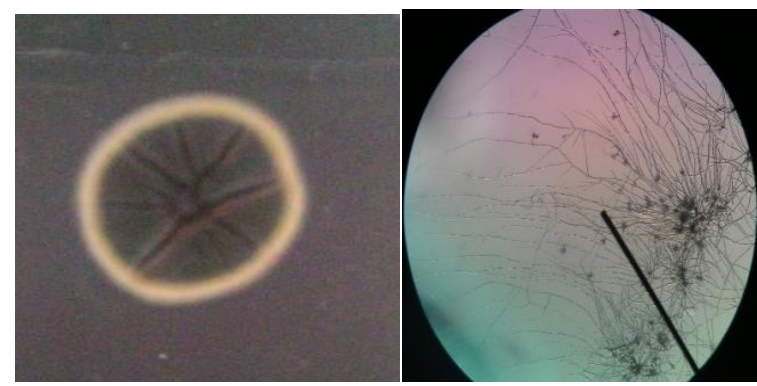

A

B

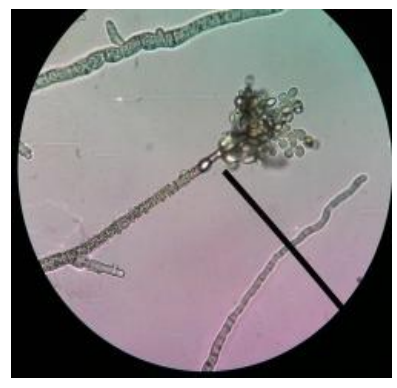

C

Gambar 1. (A) Koloni jamur Penicillium sp. (B) Penicillium sp. perbesaran $100 \mathrm{x}$ menunjukkan hifa bersepta dan badan buah berbentuk seperti sapu (C) Badan buah Penicillium sp., beserta sterigma dan konidia dengan perbesaran 1000x.

(sumber: dokumentasi pribadi)
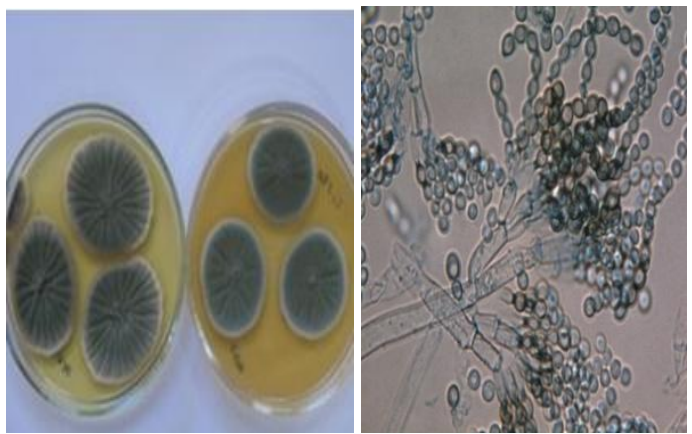

Gambar 2. Koloni jamur Penicillium sp. (kiri) dan Penicillium sp. dilihat secara mikroskopik (kanan). (sumber: www.ejbiotechnology.info danwww.pinterest. om)

Spesies dari Penicillium biasanya merupakan kontaminan di berbagai substrat 
dan telah diketahui sebagai produsen mikotoksin (asam penisilat) yang potensial. Identifikasi secara tepat sangat penting dilakukan dalam menganalisa Penicillium yang menjadi kontaminan dalam makanan. Baru-baru ini, infeksi paru-paru dan diseminasi yang diakibatkan oleh Penicillium telah dilaporkan, penyebab utamanya adalah $P$. marneffei yang berada di dalam tubuh pasien penderita AIDS (Ellis, 2015).

\section{Trichophyton spp.}

Genus Trichophyton biasanya ditandai oleh perkembangan dari kedua dinding halus makro- dan mikrokonidia. Makrokonidia sebagian besar terbentuk lateral secara langsung pada hifa atau pada pedikel yang pendek, dan memiliki dinding yang tipis atau tebal, bentuknya clavate sampai fusiform, dan memiliki ukuran dari 4-8 x 8-50 mm. Jumlah makrokonidia sedikit atau tidak ada pada beberapa spesies. Mikrokonidia berbentuk bulat, piriformis sampai clavate atau bentuknya tidak beraturan dan memiliki ukuran dari 2-3 x 2-4 mm. Kehadiran mikrokonidia membedakan genus ini dari Epidermophyton dan dinding halusnya, sebagian besar makrokonidia yang sessile membedakannya dari Microsporum (Watanabe, 1937).

Trichophyton terbagi ke dalam dua kelompok yang dapat dikenali secara langsung oleh mikroskop, yaitu (Ellis et al., 2007):

a) Spesies yang biasa menghasilkan mikrokonidia, makrokonidia mungkin ada atau tidak, yaitu $T$. rubrum, $T$. interdigitale, T. mentagrophytes, $T$. equinum, T. erinacei, $T$. tonsurans, $T$. terrestre dan pada tingkat lebih rendah T. verrucosum, yang dapat menghasilkan konidia di beberapa media.

b) Spesies yang biasanya tidak menghasilkan konidia. Chlamydospora atau struktur hifa lainnya mungkin ada, tetapi pada umumnya tidak dikenali oleh mikroskop; seperti $T$. verrucosum, $T$. violaceum, $T . \quad$ concentricum, $T$. schoenleinii dan T. soudanense.

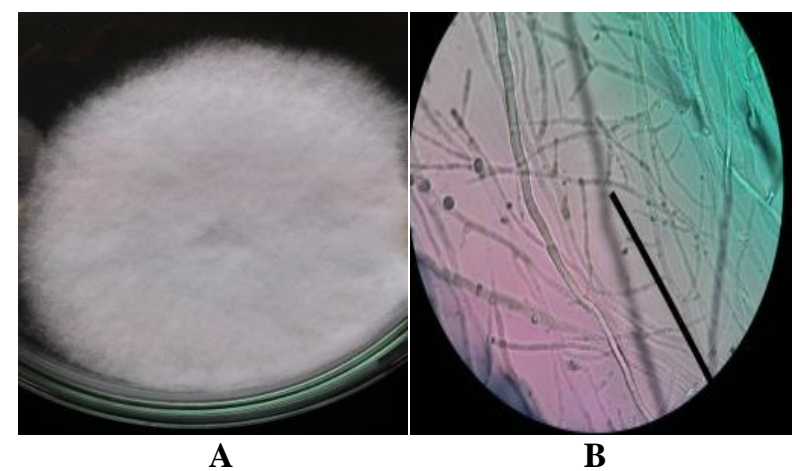

Gambar 3. (A) Koloni dari Tricophyton spp. (B) Tricophyton dilihat secara mikroskopik dengan perbesaran 1000x, terlihat adanya makrokonidia dan mikrokonidia.

(sumber: dokumentasi pribadi)
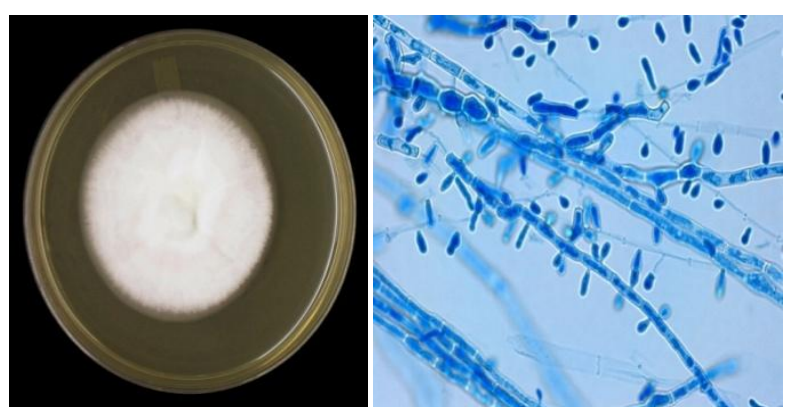

Gambar 4. Koloni dari Tricophyton spp. (kiri) dan Tricophyton dilihat secara mikroskopik (kanan). (sumber: thunderhouse4-yuri.blogspot.com)

Trichophyton merupakan salah satu parasit diantara dermatofit. Genus Trichophyton terdiri dari sejumlah spesies penting yang merupakan agen penyebab dermatofitosis pada hewan dan manusia, seperti tinea dan kurap.Trichophyton juga merupakan penyebab infeksi pada rambut dan kulit, terutama kutu air (Tinea pedis), dan infeksi pada kuku manusia.

\section{Trichophyton interdigitale}

Bentuk koloni dalam Saburoud Dextrose Agar biasanya datar, berwarna putih hingga krem dalam warna, dengan permukaan seperti ditabur dengan tepung dan dapat berwarna kekuningan serta cokelat kemerahmudaan, sering menjadi lebih gelap merah-coklat seiring dengan pertambahan usia. Banyak mikrokonidia berbentuk subspherical sampai pyriform, sesekali terdapat hifa spiral dan chlamydosporaberbentuk bola, menjadi lebih berlimpah dalam kultur yang lebih tua. Dinding makrokonidia ramping, berbentuk clavate, dan halus, makrokonidia multiseptat 
juga kadang terdapat dalam beberapa kultur (Ellis et al., 2007).

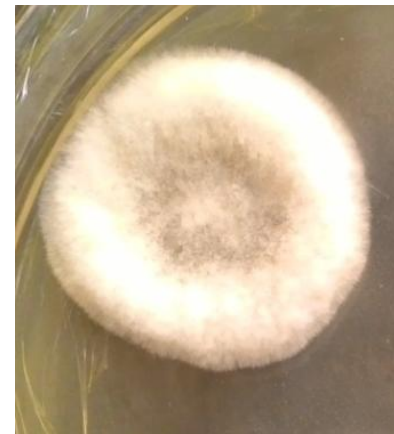

A

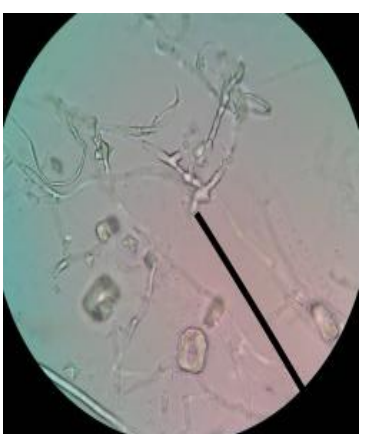

B
Gambar 5. (A) Koloni dari Trichophyton interdigitale berwarna putih dan datar (B) Trichophyton interdigitale dilihat secara mikroskopik dengan perbesaran 1000x (sumber: dokumentasi pribadi)
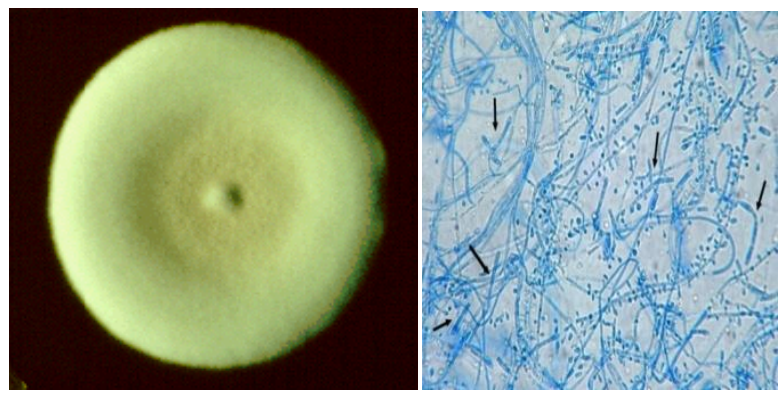

Gambar 6. Koloni dari Trichophyton interdigitale (kiri) dan Trichophyton interdigitale dilihat secara mikroskopik (kanan).

(sumber: www.mycology.adelaide.edu.au dan www.huidziekten.nl)

Trichophyton interdigitale adalah jamur anthropophilic yang tersebar di seluruh dunia dan merupakan penyebab umum dari tinea pedis, terutama jenis vesikular, tinea corporis, dan kadang-kadang menginfeksi bagianbawah lempeng kuku. Spesies ini tidak diketahui menyerang rambut secara in vivo, tetapi menghasilkan perforasi rambut secara in vitro (Ellis et al., 2007).

\section{Geotrichum spp.}

Spesies dari genus Geotrichum menghasilkan rantai hialin, halus, bersel satu, berbentuk subglobose sampai silinder, arthroconidia berlendir (ameroconidia) oleh fragmentasi holoarthric dari hifa yang tidak terdiferensiasi. Arthroconidia yang cukup bervariasi dalam ukuran, dapat berkecambah di salah satu ujung cabang dan membentuk kuncup. Namun, yang terakhir berkembang menjadi miselium berseptat. Produksi blastokonidia tidak ditemukan dalam genus ini. Karakteristik ini yang membedakan genus Geotrichumdari Trichosporon, yang biasanya tidak menghasilkan blastokonidia(Watanabe, 1937).

Pada Sabouraud dekstrosa agar, koloni tumbuh secara cepat, berbentuk datar, berwarna putih hingga krem, kering dan halus seperti tidak memiliki pigmen. Hifa dilapisi hialin, memiliki septat, bercabang dan memecah menjadi rantai hialin, halus, bersel satu, arthrokonidia berbentuk subglobose sampai silinder. Ukurannya sekitar 6-12 x 3-6 um dan dipisahkan oleh pemisahan septum ganda (Ellis, 2015).

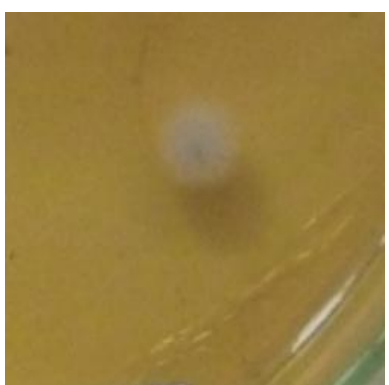

A

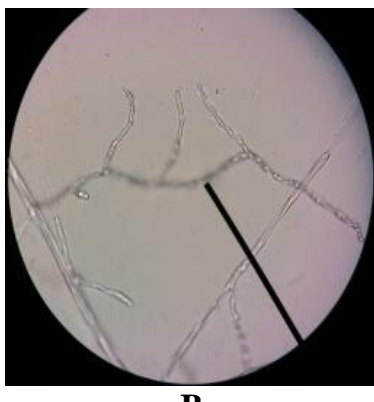

B
Gambar 7. (A) Koloni dari Geotrichum spp. berwarna putih (B) Geotrichum spp. dilihat secara mikroskopik, terlihat hifa berseptat (Arthrokonidia) yang dilapisi oleh hialin dengan perbesaran 1000x.

(sumber: dokumentasi pribadi)

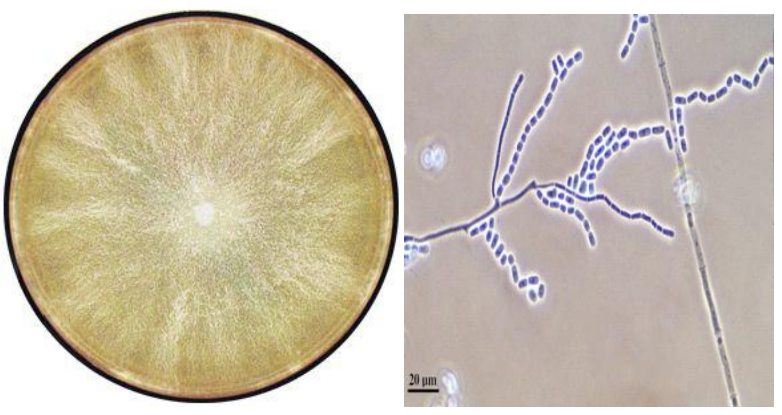

Gambar 8. Koloni dari Geotrichum spp. (kiri) dan Geotrichum spp. dilihat secara mikroskopik (kanan). (sumber: $w$ ww.pinterest.com dan www.caltexmoldservi ces.com)

\section{Geotrichum candidum}

Geotrichum candidum adalah jamur yang paling umum dan dapat ditemukan di seluruh dunia. G. candidum hidup secara saprofit dan ditemukan pada berbagai buahbuahan dan sayuran. Spesies ini juga diyakini menjadi bagian dari kulit normal dan flora usus. Telah dilaporkan bahwa Geotrichum candidum dapat menyebabkan penyakit pada 
manusia yang memiliki sistem imun rendah. Ini dapat mempengaruhi, terutama pada pasien dengan penyakit sistemik seperti diabetes melitus dan neoplasma. Secara klinis mirip dengan kandidiasis dan dapat menyebabkan infeksi mulut, vagina, kulit atau infeksi sistemik. Ada beberapa laporan dalam literatur bahwa Geotrichum dikatakan telah menginvasi jaringan. Infeksi diseminata juga telah dilaporkan dalam literatur pada pasien dengan tingkat keganasan yang tinggi (Verghese and Ravichandran, 2003).

Koloni Geotrichum candidum tumbuh dengan cepat, berbentuk datar, berwarna putih hingga krem, kering dan halus tanpa pigmen terbalik. Hifa yang hialin, berseptat, bercabang dan memecah menjadi rantai hialin, halus, bersel satu, subglobose untuk arthroconidia silinder. Berukuran 6-12 x 3-6 mm dan dipisahkan oleh pemisahan septum ganda (Ellis et al., 2007).

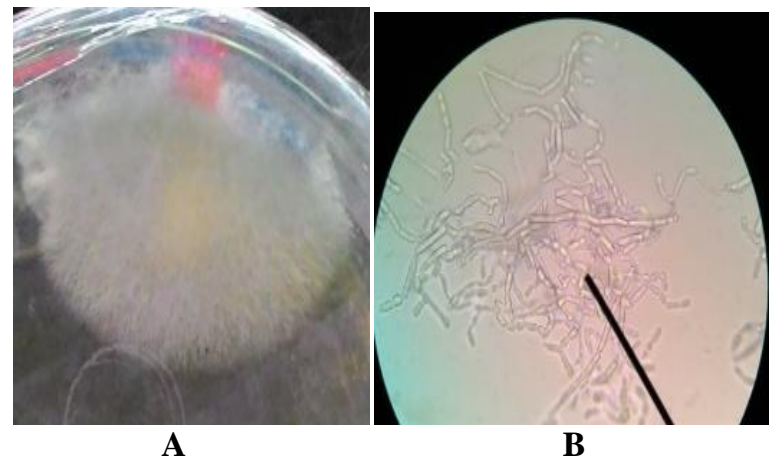

Gambar 9. (A) Koloni dari Geotrichum candidum berwarna putih (B) Geotrichum candidum dilihat secara mikroskopik, terlihat arthrokonidia dengan perbesaran 1000x.

(sumber: dokumentasi pribadi)
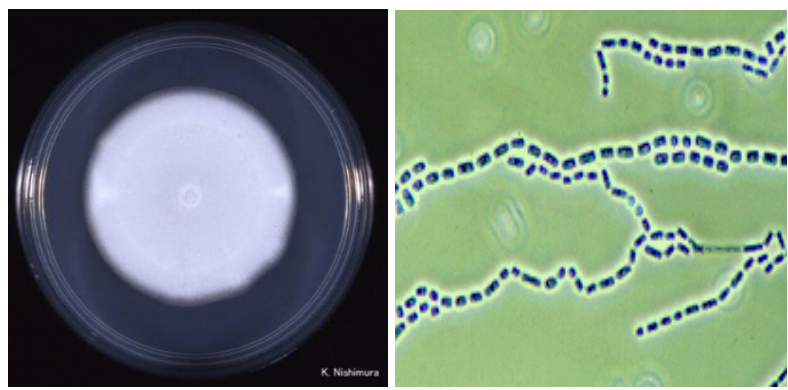

Gambar 10. Koloni dari Geotrichum candidum (kiri) dan Geotrichum candidum dilihat secara mikroskopik (kanan).

(sumber: $w w w . p f . c h i b a u . a c . j p$ dan www.mycology.adel aide.edu.au)

\section{Microsporumcanis}

Koloni dalam Agar Sabouraud berbentuk datar, menyebar, berwarna putih hingga krem,

dengan permukaan seperti kapas yang padat yang dapat menunjukkan beberapa alur radial. Koloni biasanya memiliki strain emas kuning kecoklatan dan pigmen kuning terbalik, tetapi koloni yang tidak memiliki pigmen juga dapat terjadi. Makrokonidia biasanya berbentuk gelendong dengan 5-15 sel, verrucose, berdinding tebal dan sering memiliki tombol terminal, 35-110 x 12-25 $\mu \mathrm{m}$. Beberapa mikrokonidia berbentuk pyriform hingga clavate. Makrokonidiaatau mikrokonidia sering tidak diproduksi pada media isolasi primer dan dianjurkan sub-kultur dibuat menjadi lacrimal Agar atau direbus dengan memoles di atas butir beras untuk merangsang sporulasi (Watanabe, 1937).

Microsporum canis adalah dermatofita zoofilik yang terdistribusi di seluruh dunia dan sering menjadi penyebab kurap pada manusia, terutama anak-anak. Menyerang rambut, kulit, dan jarang menyerang kuku. Kucing dan anjing adalah sumber utama infeksi. Microsporummenginvasi rambut, kemudian menunjukkan infeksi ektotriks dan berpendar terang kehijauan-kuning di bawah sinar ultraviolet (Ellis, 2015).

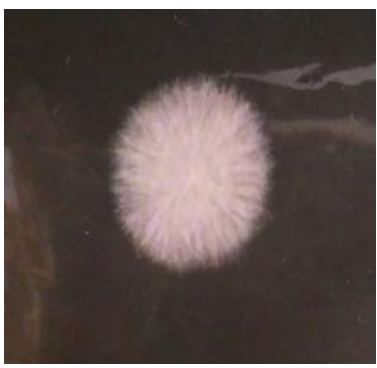

A

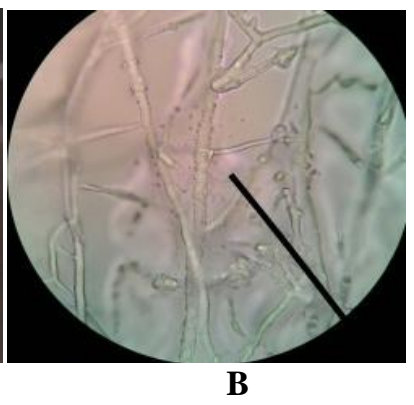

Gambar11. (A) Koloni dari Microsporum canis berwarna putih (B) Microsporum canis dilihat secara mikroskopik dengan perbesaran 1000x. (sumber: dokumentasi pribadi)
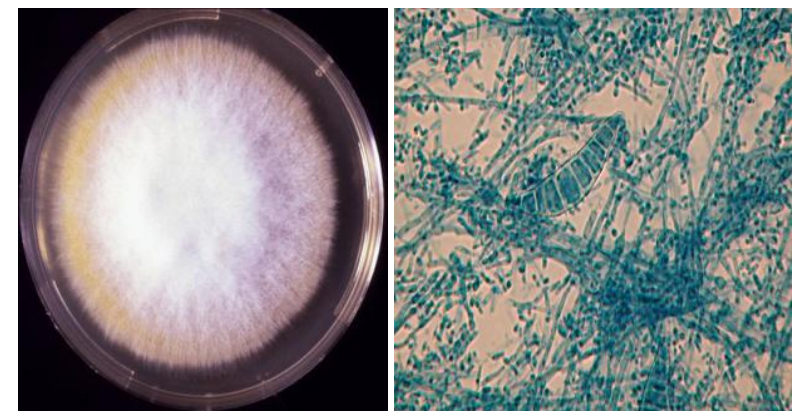

Gambar 12. Koloni dari Microsporum canis (kiri) dan Microsporum canis dilihat secara mikroskopik (kanan). (sumber: eol.org danlabmed.ucsf.edu) 


\section{Mycocladus corymbifer}

Genus Mycocladusditandai dengan diferensiasi hifa ke lengkungan bantalan stolon, terdapat sporangiospora verticillate di ruas tersebut, dan rhizoids terbentuk pada titik kontak dengan substrat (node). Karakteristik ini membedakan genusMycocladusdari genus Rhizopus, dimana sporangia timbul dari node dan karena itu ditemukan di balik rhizoids. Sporangia yang relatif kecil, bulat, pyriform atau berbentuk buah pir dan didukung oleh karakteristik apophysis berbentuk corong. Ciri ini dapat membedakan Mycocladus dari genera Mucor dan Rhizomucor, yang memiliki sporangia besar dan berbentuk bulat tanpa apophysis. Genus Mycocladusberisi empat spesies dan sebagian diantaranya adalah saprofit. Mycocladus corymbiferadalah jamur patogenyang menyebabkan infeksi pada manusia dan hewan, namun Lichtheimia ramosa juga telah dilaporkan sebagai patogen manusia meskipun status spesies jamur ini masih kontroversial (Ellis, 2015).

Koloni memiliki tingkat pertumbuhan yang cepat, floccose, putih pada awalnya dan kelamaan menjadi pucat abu-abu, tinggi sekitar 1,5 cm. Sporangiospora dilapisi hialin, sederhana atau kadang-kadang bercabang, tumbuhsecara soliter dari stolons, dalam tiga kelompok, atau dalam satu sampai tujuh kelompok. Rhizoids sangat jarang diproduksi dan mungkin sulit untuk menemukan tanpa bantuan mikroskop binokuler untuk memeriksa koloni pada permukaan agar. Sporangia kecil (dengan diameter10-40 $\mu \mathrm{m}$ ) dan biasanya berbentuk piriformis dengan karakteristik columella yang berbentuk kerucut dikenal dengan apophysis, sering dengan proyeksi pendek di bagian atas. Sporangiospores bervariasi dari bentuk subglobose sampai oblong-ellipsoidal (3-7 x 2,5-4,5 m), berwarna seperti hialin sampai abu-abu terang dan berdinding halus. Suhu: $35-37^{\circ} \mathrm{C}$ optimal; $45^{\circ} \mathrm{C}$ maksimal (Ellis et al., 2007).

Mycocladus corymbifer merupakan patogen umum pada manusia, menyebabkan infeksi paru-paru, rhinocerebral, diseminasi, CNS atau jenis infeksi kulit. Mycocladus corymbiferjuga sering dikaitkan dengan penyakit hewan, terutama aborsi mikotik. Mycocladus corymbifermemiliki distribusi di seluruh dunia, sebagian besar berasosiasi dengan tanah dan sisa-sisa tanaman yang membusuk (Ellis, 2015).

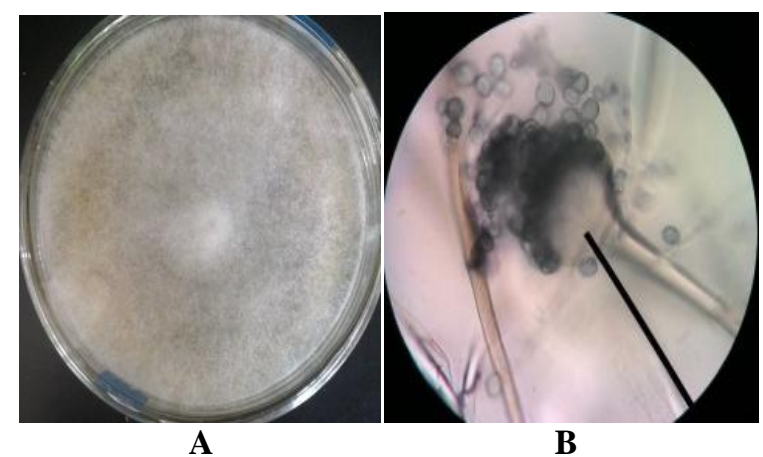

Gambar 13. (A) Koloni dari Mycocladus corymbiferberwarna putih dan hifanya berbentuk seperti serabut (B) Sporangia dari Mycocladus corymbifer dilihat secara mikroskopik dengan perbesaran 1000x. (sumber: dokumentasi pribadi).

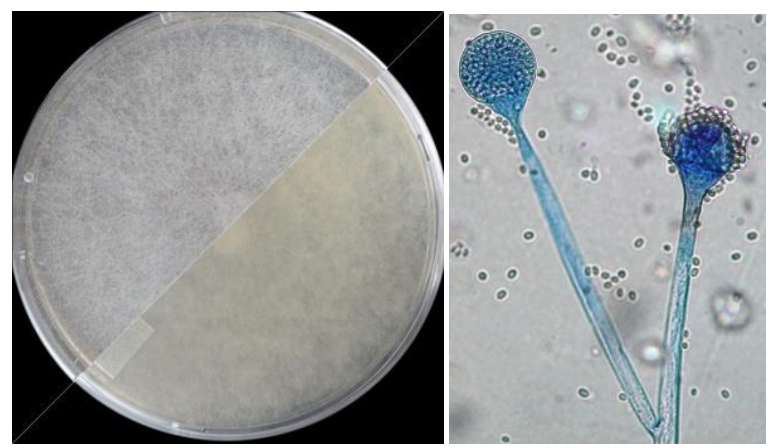

Gambar 14. Koloni dari Mycocladus corymbifer (kiri) dan sporangia dari Mycocladus corymbifer (kanan). (sumber: $\underline{w w w . i n s p q . q c . c a}$ dan $\underline{w w w . m y c o l o g y . a d e l a i d e}$ .$\underline{. e d u . a u)}$

Berdasarkan hasil penelitian Isolasi dan Identifikasi Jamur Patogen pada Air Sumur di Wilayah Pemukiman Warga RW 05-08 dan Air Sungai Cilaki, Desa Karangwangi, Cianjur, Jawa Barat, maka dapat disimpulkan bahwa :

1. Kualitas air sumur RW 05-08 dan air sungai Cilaki Desa Karangwangi secara mikrobiologis adalah kurang baik karena kehadiran jamur patogen di dalamnya. Air sumur yang paling banyak mengandung koloni jamur patogen yaitu air pada sumur RW 06 sebanyak $2,75 \times 10^{4} \mathrm{sel} / \mathrm{ml}$.

2. Dari seluruh sampel air sumur dan sungai, ditemukan sebanyak 9 spesies jamur patogen, dengan genus Penicillium sebanyak 2 spesies, Trichophyton sebanyak 3 spesies, Geotrichum sebanyak 2 spesies, Microsporum dan Lichtheimia masing-masing sebanyak 1 spesies.

3. Sebagian besar warga sekitar sumber air yang biasa menggunakan air sumur dan 
sungai untuk kebutuhan sehari-hari tidak merasakan dampak apapun setelah mengkonsumsi air dari sumber air tersebut. Tetapi sebagian kecil lainnya, terutama anak-anak sering menderita gatal-gatal pada kulit.

\section{DAFTAR PUSTAKA}

Alexopoulos, C.J., C.W. Mims, and M. Blackwell. 1996. Introductory Mycology. John Wiley and Sons, Inc. Canada.

Cooke, M.C. 2009. Fungi: Their Nature and Uses. D. Appleton and Company, 549 and 551 Broadway. New York.

Defra. 2011. A Review of Fungi in Drinking Water and The Implications for Human Health. Final Report Bio Intelligence Service. France.

Ellis, David. 2015. Mycology Online. http://www.mycology.adelaide.edu.au/ Fungal_Descriptions/Hyphomycetes_\%28 hyaline\%29/Penicillium/. Diakses pada 20 Juni 2015 pukul 06.30.

Ellis, David., Stephen Davis, Helen Alexiou, Rosemary Handke, and Robyn Bartley. 2007. Description of Medical Fungi Second Edition. School of Molecular and Biomedical Science University of Adelaide. Adelaide, Australia.

Elmeidian, M. 2010. Profile Desa Karang Wangi Kecamatan Cidaun Kabupaten Cianjur Propinsi Jawa Barat.

http://krwangi.blogspot.com/2010/04/pro filedesa-karang-wangi-kecamatan. html. Diakses pada 10 Maret 2015 pukul 05.37.

Fardiaz, S., 1992.Mikrobiologi Pangan 1. PT Gramedia Pustaka Utama. Jakarta.

Hageskal, Gunhild., Nelson Lima and Ida Skaar. 2009. The Study of Fungi in Drinking Water. Mycological Research 113: $165-172$.

Ichsan. 1979. Kesehatan Lingkungan. PT. Rora Karya. Jakarta.Karangwangi. Profile Desa Karangwangi. http://kknm.unpad.ac.id/karangw angi/profiledesa-karangwangil. Diakses pada 19 Maret 2014 pukul 07.07.

Purwantisari, Susiana dan Rini Budi Hastuti. 2009. Isolasi dan Identifikasi Jamur Indigenous Rhizosfer Tanaman Kentang dari Lahan Pertanian Kentang Organik di Desa Pakis, Magelang. BIOMA Vol. 11 No.2.

Reseck, Jr. John. 1988. Marine Biology Second Edition. A Reston Book Prentice Hall, Englen Wood Diff, N.J. UK.

Schlegel, H. and K. Schmidt.1994. Mikrobiologi Umum Edisi ke6.Diterjemahkan oleh R. M. Tedjo Baskoro.UGM-Press.Yogyakarta.

Slamet, S. 1996. Kesehatan Lingkungan. Gadjah Mada University Press.Yogyakarta.

Sukadi. 1999. Pencemaran Sungai Akibat Buangan Limbah dan Pengaruhnya terhadap BOD dan DO.Jurusan Pendidikan Teknik Bangunan Fakultas Pendidikan Teknologi dan Kejuruan Institut Keguruan dan Ilmu Pendidikan. Bandung.

Verghese, S., and P. Ravichandran. 2003. Geotrichum candidum Infection in a Renal Transplant Recipient. Indian Journal of Nephrology 2003:13; 72-74.

Waluyo, L., 2004. Mikrobiologi Umum. UMM Press. Malang.

Watanabe, T. 1937. Pictorial Atlas of Soil and Seed Fungi: Morphologies of Cultured Fungi and Key to Species. Second Edition. CRC Press. New York.

Yusuf, Y., Fatimah N., dan Rusdi N.K. 2011. Analisa Kandungan Air Sumur Warga RT 12, 17 dan 18 RW 09 Kelurahan Kelapa Dua Wetan Kecamatan Ciracas, Jakarta Timur. Proseding Penelitian Bidang Ilmu Eksakta 2011. 